NATALIA JARSKA

Tadeusz Manteuffel Institute of History, Polish Academy of Sciences, Warsaw

\title{
A PATRIARCHAL MARRIAGE? THE WOMEN'S MOVEMENT AND THE COMMUNIST PARTY IN POLAND (1945-1989)
}

Abstract: This article is a contribution to the debate on the role and character of women's organizations in Eastern Europe after 1945, including the role they played in the process of women's emancipation. The purpose of the article is to offer insight into the relation between the communist party (that is the PPR and its successor the PZPR) and the women's movement in Poland in the years 1945-89 and to provide a new interpretation of the movement's history under state socialism. I contend that women's organizations should be viewed as part of the communist system and the roles they played should be understood in the context of the policies pursued by the communist states.

Keyw ords: the women's movement, state socialism, Poland, the League of Women, the communist party.

Over the past few years feminist historiography has been engaged in a debate on the role and character of women's organizations in the state socialist countries after 1945 . This article is a contribution to that debate. By analysing some aspects of the women's movement in Poland, especially its relationship to the communist party and programme, I seek to highlight issues that have so far been omitted from researchers' attempts to grasp the nature of these kinds of organizations. Debate on their relationship to the party, especially after 1956, has been absent from Polish historiography.

Attempts to investigate women's organizations in Poland in the years 1945-89 have been undertaken only sporadically. Unlike other mass organizations (especially youth organizations) those intended for women have never been subject to a thorough analysis. The League of Women (the LK), the largest and most important structure operating 
throughout the post-war period, has aroused the greatest interest, ${ }^{1}$ and the most important research into its history so far has been conducted by Barbara Nowak, who devoted her doctoral dissertation to the topic (although her work remains unpublished, it is known to scholars dealing with the subject), ${ }^{2}$ and by Dariusz Jarosz who in his article on the League over the years 1945-57 traces the evolution of its goals and methods, revealing the mechanism of its subordination to the communist party. ${ }^{3}$ We know a relatively large amount about the existence of the women's movement during the first post-war years and also the Stalinist era. ${ }^{4}$ The movement's history in later years has been covered by Magdalena Grabowska who focused her attention on the identity of particular activists, and by Katarzyna Stańczak-Wiślicz who was concerned with the Home Economics Committee affiliated to the League of Women. ${ }^{5}$ There are several articles on the League's regional and local structures, as well as on other organizations that made up the women's movement in the Polish People's Republic (the PRL) (the Circles of Rural Housewives (the KGW), the Militia Families' Clubs, The Women's Council attached to the CRZZ (Central Council of Trade Unions), The National Section of Cooperative Women) ${ }^{6}$

${ }^{1}$ In the years $1945-48$ as the Women's Socio-Civic League, 1948-81 as the League of Women and in the last decade of communist Poland as the League of Polish Women.

${ }^{2}$ Barbara Nowak, 'Serving Women and the State. The League of Women in Communist Poland', PhD diss., Ohio State University, 2004; eadem, "“Where Do You Think I Learned How to Style My Own Hair?”: Gender and Everyday Lives of Women Activists in Poland's League of Women' in Gender Politics and Everyday Life in State Socialist Eastern and Central Europe, ed. Shana Penn and Jill Massino, New York, 2009, pp. 45-58; eadem, 'Constant Conversations: Agitators in the League of Women in Poland during the Stalinist Period', Feminist Studies, 31, 2005, 3, pp. 488-518.

${ }^{3}$ Dariusz Jarosz, 'Idee, programy i realia. Funkcje Ligi Kobiet w porządku instytucjonalnym Polski Ludowej (1945-1957)', in Działaczki społeczne, feministki, obywatelki... Samoorganizowanie się kobiet na ziemiach polskich po 1918 roku (na tle porównawczym), 2 vols, ed. Agnieszka Janiak-Jasińska, Katarzyna Sierakowska and Andrzej Szwarc, Warsaw, 2008-09, vol. 2, pp. 307-30.

${ }^{4}$ Natalia Jarska, 'Frauen in den polnischen kommunistischen Parteien PPR/ PZPR - die Paradoxe der Frauenpolitik', Jahrbuch für Historische Kommunismusforschung, 2015, pp. 75-94; Anna Nowakowska-Wierzchoś, 'Społeczno-Obywatelska Liga Kobiet (1945-1949) i Związek Kobiet Polskich im. Marii Konopnickiej we Francji (1944-1950) - dokumenty programowe', Komunizm. System, ludzie, dokumentacja, 2013, pp. 251-79; Malgorzata Fidelis, Women, Communism, and Industrialization in Postwar Poland, Cambridge, 2010 (Chapter 1 'Visions of Equality: the state, the Church, and Women's Sections addresses the issue of Women's Sections within the PPR and the PPS').

${ }^{5}$ Magdalena Grabowska, 'Bits of Freedom: Demystifying Women's Activism under State Socialism in Poland and Georgia', Feminist Studies, 43, 2017, 1, pp. 141-68; Katarzyna Stańczak-Wiślicz, 'Household as a Battleground of Modernity. Activities of the Home Economics Commitee Affiliated to the League of Women (1957-80)', APH, 115, 2017, pp. 123-50.

${ }^{6}$ The structure of the official women's movement in Poland is discussed in a later 
The topic has received little attention due to the lack of files from the General Board of the League of Women (the ZGLK) and, it seems, due to a stereotyped view of the League as one of the party's façade institutions, a rather uninteresting 'power transmission belt'. Our knowledge of other organizations such as the National Council of Polish Women (the KRKP) (1966-83) is very limited, as is our knowledge of the women's trade union structures.

The history of women's organizations in communist Poland has not yet conceptualized in a way which would enable us to understand the role they played in the state-party system. Barbara Nowak sought to answer the question of whether the League served the party more than it served women. The perspective from which she has approached the subject is similar to analysis of the role and character of women's organizations in the Soviet bloc. Did they work to women's advantage or were they used as 'the communist party's power transmission belts'? The long-running debate among gender historians has centred around the agency of female activists and the 'state/communist feminism'. Going beyond the issue of women's organizations, it concerns itself with the idea of gender equality and investigates the extent to which communist states supported women. In a 2007 debate held in the pages of the journal Aspasia issued at the Central European University, Mihaela Miroiu claimed that communism was a 'state patriarchy'. In her opinion it 'feminised' the whole society, leaving no room for autonomous activity. ${ }^{7}$ A polemical view was expressed by Kassimira Daskalova, who discerned 'women-friendly actions' [on the part of the communist state $].{ }^{8}$ Claiming that autonomy could be understood in a variety of ways, she argued, following Michael Foucault, that in

part of this article. Natalia Jarska, 'Komisja Kobieca CRZZ wobec problemów kobiet pracujących (1956-1970)', Polska 1944/45-1989. Studia i materiały, 9, 2010, pp. 305-28; eadem, 'Liga Kobiet w terenie. Działalność Zarządu Dzielnicowego Poznań-Wilda w latach 1956-1966', in Letnia Szkoła Historii Najnowszej 2009. Referaty, ed. Łukasz Kamiński and Tomasz Kozłowski, Warsaw, 2010, pp. 149-58; Agnieszka Stasiewicz, 'Działalność Społeczno-Obywatelskiej Ligi Kobiet w latach 1945-1948 na Białostocczyźnie w świetle dokumentów PPR', in Kobiety 'na zakręcie' 1933-1989, ed. Ewa Chabros and Agnieszka Klarman, Wrocław, 2014, pp. 51-78; Natalia Jarska, 'Between the Rural Household and Political Mobilization - The Circles of Rural Housewives in Poland 1946-1989', in Countryside and Communism in Eastern Europe: Perceptions, Attitudes, Propaganda, ed. Sorin Radu and Cosmin Budeanca, Zürich, 2016; Anna Marcinkiewicz-Kaczmarczyk, 'Koła Rodzin Milicyjnych - powstanie, organizacja i praca propagandowa', Czasopismo Naukowe Instytutu Studiów Kobiecych, 2017, 1, pp. 28-47.

${ }^{7}$ Mihaela Miroiu, 'Communism Was a State Patriarchy, Not State Feminism', Aspasia, 1, 2007, pp. 197-201.

${ }^{8}$ Kassimira Daskalova, "How Should We Name the "Women-Friendly" Actions of State Socialism?', Aspasia, 1, 2007, pp. 214-19. 
modern society the achievement of perfect autonomy is only a mirage. She also called for further research into the means of supporting women through state socialism. Although the research Daskalova had in mind has undergone significant development, Susan Zimmermann's conclusion that there is 'considerable disagreement and debate over the actual effect of these changes, notably the relationship between continuity and change in gender politics and gender relations under state socialism, that between the socialist/communist ideal of emancipation and the reality of state socialism and thus over the character of the socialist gender regime, and over the motivation behind socialist state gender politics' still remains valid. ${ }^{9}$ The last decade has seen the appearance of new research into the women's movement in the Soviet bloc countries. Its authors have attempted to look upon women's organizations not only as supporting women, but even as promoting feminism. ${ }^{10}$

One of the recent highlights of the debate is published in the pages of Journal of Women's History, ${ }^{11}$ the polemic between Nanette Funk and Kristen Ghodsee. The former has referred to authors appreciating the role of the women's movement as 'feminist revisionist scholars'. In the opinion of these scholars, the movement was 'crucial in promoting women's political, economic and social rights, and emancipation', and its 'leaders designed an original, progressive agenda on the "woman's question". ${ }^{12}$

Funk argues that the truly independent women's movement was suppressed in communist states and officially approved organizations were headed by party functionaries. She points out the necessity of drawing a distinction between grass-roots activism and rank-and-file non-conformism on the one hand, and the subjection of leaders of women's orga-

${ }^{9}$ Susan Zimmermann, 'Gender Regime and Gender Struggle in Hungarian State Socialism', Aspasia, 4, 2010, pp.1-24.

${ }^{10}$ Kristen Ghodsee, 'Pressuring the Politburo: The Committee of the Bulgarian Women's Movement and State Socialist Feminism', Slavic Review, 73, 2014, 3, pp. 538-62 (pp.538-40); Raluca Maria Popa, 'Translating Equality between Women and Men across Cold War Divides: Women Activists from Hungary and Romania and the Creation of International Women's Year', in Gender Politics and Everyday Life in State Socialist Eastern and Central Europe, pp. 59-74; Chiara Bonfiglioli, 'Women's Political and Social Activism in the Early Cold War Era: The Case of Yugoslavia', Aspasia, 8, 2014, pp. 1-25.

${ }^{11}$ Nanette Funk, 'A Very Tangled Knot: Official State Socialist Women's Organizations, Women's Agency and Feminism in Eastern European State Socialism', European Journal of Women's Studies, 21, 2014, 4, pp. 344-60; Kristen Ghodsee, 'Untangling the Knot: A Response to Nanette Funk', European Journal of Women's Studies, 22, 2015, 2, pp. 248-52.

${ }^{12}$ Funk, 'A Very Tangled Knot', p. 346 (Funk quotes here works by R.M. Popa and C. Bonfiglioli, referenced above). 
nizations to the party on the other. She also claims that "being active is not necessarily being proactive' and 'it is only proactive agency, not just being active, that realizes the goal of a search for women as subjects and not just objects of emancipation'. In her opinion women's organizations, which she describes as 'reactive', ${ }^{13}$ were just tools the party used to further its own goals, while reactivity and passive resistance are not regarded by her as sufficient for the female activists to be called 'feminists'. Not only were they ineffective in their efforts to develop various initiatives, but their actions were sometimes to women's detriment. Funk concludes by calling for further, more detailed research: 'if the region's women and gender studies are to thrive, they have to be nuanced, true to the complex, often contradictory stories about official women's organizations and gender policy in state socialism'.

In a brief polemic with this clear-cut view, Kristen Ghodsee focused on the meaning of the concept of agency. Ghodsee sought to reduce Funk's argument to absurdity by pointing out that a proactive conduct is always limited regardless of the political system under which it takes place. She questioned the idea of tension between various organizations' own programs and those imposed by the communist party. Many female activists were at the same time communists and their commitment to advancing women's cause was strictly bound up with their ideological political preferences. She also observed that Funk had confined feminism to within the limits of Western liberalism, and, in Ghodsee's opinion, women's organizations operating under the communist system focused on the improvement of women's material situation rather than on the implementation of a liberal idea of freedom. From this she derived a broader and more inclusive understanding of feminism as aiming to improve women's lives and to eliminate discrimination. In her exchange with Funk, Ghodsee focused her attention exclusively on the notions of agency and feminism, leaving all other points the former raised untouched (for example, a lack of effectiveness).

Thus it remains important for feminist historiography to answer the question whether, and to what extent, women's organizations operating under state socialism actually served women's needs and, consequently, whether they can be included in the feminist movement's tradition. Can their activists be regarded as feminist? The organizations in question are 'attacked' for not having been autonomous. However, claims about their inability to act on their own seem to perpetuate cold-war stereotypes in the Humanities. The whole discussion can also be said to reflect a more

\footnotetext{
${ }^{13}$ Funk, 'A Very Tangled Knot', p. 349.
} 
general issue of East-Central Europe's place in the history of emancipation and feminism. ${ }^{14}$ The 'inclusive approach' appreciates the role of the emancipation movement and its activists who, it is stressed, were ahead of western feminism in advancing various ideas. The adoption of a critical view, in turn, leads to the denouncement of the women's organizations as undemocratic and constituting an extension of the state patriarchy. There is thus a clear political dimension to the debate.

Although there is much to be said in favour of each perspective, both seem to limit our view of the problem. The past certainly should not be observed through the prism of cold war stereotypes and historical interpretations should not be based on all-embracing dichotomies. This is why transnational research into women's movements, including Women's International Democratic Federation, is so significant. ${ }^{15}$ Equally useless is the totalitarian paradigm in which the societies of Soviet Bloc countries are given the role of passive objects deprived of any ability to act on their own and used by the authorities to further the policy of communist states. ${ }^{16}$ This is actually the conclusion to be drawn from Nanette Funk's theses. On the other hand, however, it is not an exaggeration to say that in the communist states the women's movement was subjugated to the ruling party. The critical perspective has the limitation of being based on concepts and categories elaborated in the West to analyse democratic societies. Unsurprisingly, the post-war history of East-Central Europe does not 'fit' into this conceptual framework. As a result, one is easily led into a view of its backwardness. The limitation of the 'inclusive' perspective, in turn, lies in the removal of the women's movement from a wider historical context, an approach likely to result in the development of uncritical views of it. The use of the concept of agency as a foundation on which to build an interpretation of the history of women's organizations under state socialism appears, at least from the historiographical perspective, to lead to futile discussions. One should also agree with the opinion that the issue calls

${ }^{14}$ See Magdalena Grabowska, 'Bringing the Second World In: Conservative Revolution(s), Socialist Legacies, and Transnational Silences in the Trajectories of Polish Feminism', Signs, 37, 2012, 2, pp. 385-411.

${ }^{15}$ Francisca de Haan, 'Continuing Cold War Paradigms in Western Historiography of Transnational Women's Organisations: The Case of the Women's International Democratic Federation (WIDF)', Women's History Review, 19, 2010, 4: International Feminisms, pp. 547-73; Celia Donert, 'Women's Rights in Cold War Europe: Disentangling Feminist Histories', P\&P, 218, 2013, suppl. 8, pp. 180-202.

${ }^{16}$ In the context of women's organizatitons the issue has been covered by Barbara Nowak. 
for stepping outside the dichotomy of wom n's and state interests. ${ }^{17}$ Similarity in both polemics (from 2007 and from 2014-15) shows that researchers have so far failed to provide satisfying answers, and that the whole debate has not been taken beyond the issues of agency, autonomy and feminism. It is hardly an encouraging conclusion.

In order to overcome the limitations mentioned above, it is necessary to elaborate an approach which would help us gain a new understanding of the women's movement in state socialist countries. This goal can only be achieved through a thorough analysis of the role of women's organizations within their social and political context. How was their structure shaped and what was their position in the system of power? Who let them and why? What problems did they tackle and why? Also of importance is the periodization of their history. ${ }^{18}$ The purpose of this article is to give answers to the first and, in part, to the third of these questions. My main aim here is to deal with the issue of the relation between the Polish United Workers' Party (the PZPR) and women's organizations existing in communist Poland. Such an approach can hopefully contribute to a more nuanced understanding of the issue of 'state feminism'. In adopting it, I put aside the agency/passivity dichotomy and the problem of whether women's organizations in communist Poland served the 'party' more than women themselves. It is not easy to resolve the issue of which actions and policies benefited women most. Its resolution requires a conceptualizsation of these 'benefits'. Debate on feminism and agency, although important from the perspective of both gender and historical studies, should not determine the way in which the problem under investigation is dealt with. I propose to look at the women's movement comprehensively, that is, in its wide social and political context, without isolating it from wider phenomena. Agency is not entirely eliminated from this perspective, but it is placed within the limits imposed, or at least approved, by the incumbent political system. There is 'feminism' too, but one existing only insofar as it coincides with the goals pursued by the state. Such organizations as the League of Women were simply part of a system that integrated women's emancipatory agenda with a variety of other policies. The organizations in question could work to women's benefit, but only insofar as their goals remained in keeping with the goals pursued by the party. In a sense this perspective makes it possible to reconcile both viewpoints, revealing where women's organizations acted independently and where they served as 'power transmission belts'. At the same time it enables us to step outside the limiting framework

\footnotetext{
${ }^{17}$ Ghodsee, 'Untangling the Knot', p. 562.

${ }^{18}$ Funk, 'A Very Tangled Knot', p. 348.
} 
within which the whole discussion has so far been held. It is also clear that despite various similarities existing between particular organizations, the levels of autonomy they enjoyed and the kind of activity in which they were involved differed depending, among other things, on both the period and the country in which they operated.

What is often left unaddressed is the question of what should be considered to be in women's interests. Our view of the history of the organizations (those existing in the Soviet bloc countries) depends on how this important question is answered. The policy in which these engaged is usually viewed through the prism of today's standards and notions of gender equality. Approached from this angle, the increase in privileges conferred on working women, including increasingly long maternity leaves, appears to express the traditional view of women as mothers. ${ }^{19}$ From this perspective, the League of Women appears to have been 'progressive' in the Stalinist period, when it promoted employment of women as qualified (and better paid) labourers, but less so in later decades when it became involved in making presentations of domestic appliances and organizing cutting and sewing workshops. However, when the public response received by the League is looked at, it transpires that the number of those who joined it in the Stalinist era is rather insignificant (at that time the League neglected the social field), while the workshops enjoyed much popularity. Women's interests are not easy to define; there are many different groups of women. In this article I focus on the interests of women's organizations, setting aside the interests and needs of women themselves. Of course, this does not mean that women's organizations did not represent certain women's interests - this was certainly the case. However, complex relations between different groups of women, including their leading and rank-and-file members, and the policy pursued by the party-state must be addressed in a separate study.

It is essential to take a look at the relations between the communist party and the women's movement, since this is the only way in which we can define the latter's place in the state system. My research shows that the communist authorities usually dictated both the tasks and operating models on the women's movement. The goals and methods of women's organizations were summed up in the slogan 'work among women' (praca wśród kobiet). The goals were in line with a certain vision of femininity and with tasks whose performance was required of women living in 'so-

${ }^{19}$ Malgorzata Fidelis, ‘Equality through Protection: The Politics of Women's Employment in Postwar Poland, 1945-1956', Slavic Review, 63, 2004, 2, pp. 301-24. 
cialist society'. Contrary to the slogans of women's emancipation, raised throughout the PRL's history, the very way in which the women's movement functioned was not emancipatory for its activists. It was an inherent part of the system, and its goals became increasingly consistent with a traditional view of women (that is, one emphasizing their private roles). This does not mean that the latter received no support from the League and the Circles of Rural Housewives. The relation between the party and the League of Women can be represented by the metaphor of a patriarchal and unbreakable marriage, one based on strict hierarchy and clearly defined roles of both spouses.

I also believe - and I am in agreement here with Kristen Ghodsee that female activists' endeavours should be conceived of in terms of their wider participation in the exercise of state power. The women's movement was an extension of the party's activity, especially at the central level, and could become an episode in one's political career. The identity of the members of the League of Women was also the identity of party activists. There was sometimes a conflict of interests, but the League's members usually internalized party orders. The structures of both organizations were mutually intertwined. Alicja Musiałowa (1911-1998), for many years head of the League of Women, served in the 1960s as chairwoman of the Social Section of the Administrative Department of the KC PZPR (Central Committee of the Polish United Workers' Party). Did she use the party to pursue the goals of the League or the other way around? Those who led the women's movement should be viewed as the system's functionaries.

The theses advanced above are based on analysis of the relation between the party and the women's movement. This analysis is in turn based on documents found in the Central Committee of the PPR (the Polish Workers' Party)/PZPR. Generated by both the communist party (decisions, analyses, notes) and the women's movement, these documents reflect relations between the party and women's mass organizations. Their analysis shows how the party shaped the movement, how it defined its meaning, and how the movement attempted to modify it. The modification took place notably when women's leaders significantly differed from party officials in their understanding of the goals to be pursued by women's organizations. It needs to be stressed that unavailability of minutes from meetings of the League's General Board rules out the possibility of knowing the background details of its activity. However we have at our disposal materials created by the National Council of Polish Women (including the minutes of its meetings), a body active between the years 1966-83, along with records of the Women's Committee of the Central Council of Trade Unions. 
The sources regarding the women's movement can also be found in different sections of the Central Committee of the PZPR (the Women's Section 1946-53, the Organizational Section, the Social Organizations, Sport and Tourism Section 1977-81, the Socio-Labour Section - the Women's Commission from 1982). This body of sources, comprising several hundred volumes of files is in my opinion sufficient to give an answer to the question on relations between the party and the women's movement in PRL. ${ }^{20}$ The analysis presented below pertains to high-level relations.

The 'women's movement' is understood here to include all the official bodies (excluding those which made up the state administration) set up to deal with women's issues. There were over a dozen of them in PRL. Some were part of larger organizations - for example, the Women's Council/Commission affiliated to the regime's trade unions (the KCZZ (Central Committee of the Trade Unions), the CRZZ) or the Circles of Rural Housewives which operated first as part of the Farmers' Self-Help Association (ZSCh) and then the Agricultural Rings Association. These bodies suffered from 'double subordination': to their parent organizations and to the League of Women (or, depending on the period, to the National Council of Polish Women). The League of Women was the largest and most important female organization in communist Poland. The Central Committee of the PPR/PZPR's sections concerned with 'women's issues' acted as intermediaries between the party and women's organizations.

In this article I discuss changes in the structure of the women's movement. Contrary to what might be expected, the structure was complex and underwent much reorganization, which was also bound up with the party's power to control the women's movement and to modify the goals it pursued (see the Annex). No attempt has so far been made to clarify this aspect of the problem. Analysis of the movement's structural evolution is here a means to reveal its relations with the party. In the following section I present women's organizations as subjects the party and analyse their role in the political system.

Structural changes and their mechanisms

The structure of the women's movement underwent several changes: in 1953, 1957, 1966, 1981 and 1983. Who initiated them, who negotiated and who confirmed? What role did female activists play in shaping their own

\footnotetext{
${ }^{20}$ Research hitherto draws mainly on party files covering the period until 1957 (Fidelis, Jarosz, Nowak).
} 
organizations? The history of the changes, their causes and effects, reveal several facts: the subordination of women's organizations to the communist party, the ambiguous position of high-ranking female activists between the party and the women's movement and the priority of goals pursued by the party over those pursued by women's organizations.

The summer of 1945 saw the establishment of the Women's Socio-Civic League (the SOLK). It was designed as a cross-party body. The PPR conceived it as a tool with which to affect women's political attitudes. ${ }^{21}$ In practice, it was dominated by PPR members and it did not take long before it became the only women's organization in Poland. ${ }^{22}$ Irena Sztachelska (1911-2010) was its first chairwoman. The League began its activity by organizing three types of units: for city housewives, rural housewives, and at women's workplaces. This initial step was followed by the establishment of women's sections and women's councils within the Trade Unions and within the Farmers' Self-Help Association. 1948 saw the emergence of the Section of the Clubs of the League's Military Families. ${ }^{23}$

In 1946 the Women's Section was established as part of the PPR's Central Committee (a pre-war communist, Edwarda Orłowska, 1906-1977, was appointed its head). A similar section was formed within the PPS (the Polish Socialist Party). The Women's Section supervised 'work among women' the goal of which was to build support for the PPR. Various organizations with no formal party ties were used as a means for the party to work towards this achievement. ${ }^{24}$ The Circles of Rural Housewives were subordinate to the newly formed Farmers' Self-Help Association. The SOLK rural units were initially transformed into the Circles of Rural Housewives whose members formally belonged to the League of Women. In 1946 the Women's Commission was set up attached to the Trade Unions' Central Committee, along with its low-level counterparts known as women's councils. Some of the councils became very active. Thus, the key spheres of activity into which the women's movement was divided began to emerge very early on, and the division continued until the end of the PRL. There was one organization for female employees (not only

21 'Rezolucja I Zjazdu PPR w sprawach organizacyjnych', in PPR. Rezolucje, odezwy, instrukcje i okólniki Komitetu Centralnego. VIII 1944-XII 1945, ed. Władysław Góra, Ryszard Halaba and Norbert Kołomejczyk, Warsaw, 1959, pp. 214-15.

${ }^{22}$ Jarosz, 'Idee, programy i realia', p. 308.

${ }^{23}$ AAN, KC PZPR, 237/V/72, Osiągnięcia i braki w pracy wśród kobiet (załącznik do tez dla Biura Politycznego KC PZPR), 1949.

24 'Instrukcja KC PPR w sprawie pracy wśród kobiet i organizowania wydziałów kobiecych w komitetach wojewódzkich PPR', in PPR. Rezolucje, odezwy, instrukcje i okólniki Komitetu Centralnego. I 1946-I 1947, ed. Władysław Góra, Ryszard Halaba and Norbert Kołomejczyk, Warsaw, 1961. 
labourers), one for women from rural areas, and one mass organization (the League of Women) aiming at the mobilization of women in political participation.

In 1948, after the unification of the PPR and the PPS, the tasks performed by the socialist party's female branch were taken over by the PZPR Women's Section, as were some of its members. This new body was put in control of the League of Women which, following its National Convention held in the autumn of 1948, was no longer called 'socio-civic'. The women's movement included the following central level bodies: the LK's General Board, the Women's Council of the General Board of the Farmers' Self-Help Association, and the CRZZ Women's Section. The movement's provincial level structure was analogous. It was controlled by the women's sections of the party's provincial committees. ${ }^{25}$ The status of the Circles of Rural Housewives had not changed, but in 1949 so-called collective membership was introduced - KGW members were inducted automatically to the League of Women.

In June 1952 the PZPR Women's Section set about developing new ways of 'working among women'. In a memorandum devoted to the issue it was proposed that the League of Women should restrict its activity in women's workplaces. ${ }^{26}$ At the beginning of 1953 the Section proposed self-dissolution. Idea to dissolve the party's 'female' structures, present since 1946, was based on some optimistic assumptions. First of all, it drew on figures allegedly indicating that the whole party took interest in 'work among women' and that women themselves were willing to join in the task of building socialism. This willingness, in turn, was believed to prove that the party no longer needed women's separate structures. However, these conclusions were certainly exaggerated. ${ }^{27}$ Ultimately, members of the Politburo Edward Ochab, Jakub Berman and Aleksander Zawadzki were entrusted with the task of drawing up the relevant document. In February 1953, in line with the above argument, the Secretariat issued a resolution 'on new ways of supervising work among women by the party's leadership'. The task was assigned to the party's organizational section. ${ }^{28}$ The Central Committee

${ }^{25}$ AAN, KC PZPR, 237/V/72, Struktura organizacyjna pracy wśród kobiet, fol. 46.

${ }^{26}$ AAN, KC PZPR, 237/V/72, Notatka Wydziału Kobiecego KC PZPR w sprawie zmiany form kierownictwa Partii pracą wśród kobiet, fol. 61.

${ }^{27}$ AAN, KC PZPR, 237/VIII-76, Uchwała o zmianie form partyjnego kierownictwa pracą wśród kobiet, 26 I 1953, fol. 2.

${ }^{28}$ We are not familiar with discussion held during the meeting of the Secretariat of the Central Committee of the PZPR's Organizational Office during which the decision regarding the adoption of the resolution was taken. However, we know that the 
of the PZPR Women's Section was thus liquidated as were its provincial level sections.

A few months later the Central Committee of the PZPR decided to liquidate the League's workplace units, which at that time constituted its primary field of activity. The step was expected to enable the organization to focus on recruiting non-working women (known as housewives). ${ }^{29}$ Interestingly, similar processes took place in Hungary and the GDR. ${ }^{30}$ As a result, however, the League grew considerably weaker. Not only did it suffer cuts in its number of employees (nearly two hundred) but it also failed to attract 'housewives'. In 1953 women activists were in part responsible for introducing measures that harmed the women's movement. Despite these changes the League of Women, subordinate to the Central Committee of the PZPR's Organizational Section, remained the foremost organization representing women's interests. Throughout the existence of communist Poland the party was in full control of the women's movement, as well as all other mass organizations of the time.

In 1957 the League underwent a significant change. Its workplace units, dissolved in 1953, were restored, and in later years they attracted many women, at least some, developing significant activities. During the political thaw which followed the events pf 1956 the League was plunged into a fierce debate which led to the articulation of its needs and interests, including the demand for restoration of its workplace units, referred to above. The League's members also raised criticism of its subordination to the party. ${ }^{31}$ Attempts to strengthen women's workplace organizations came as a response to grass-roots demands. During the political thaw the need for the League to reinstate its workplace units was expressed at its meetings and in the pages of its journal. The 1953 decision was criticized (even Alicja Musiałowa took a critical view of it). ${ }^{32}$ The period also witnessed the re-establishment of women's trade union councils and the creation of the National Section of Cooperative Women. Some women's organizations' proposals gained acceptance from the communist authorities and some did not (for example the party rejected the idea of creating a separate organization for women from rural areas). 'The Central Committee's Secretariat has found it inadvisable to create a separate organization for women from the rural

task of drawing it up was entrusted to three high-ranking members of the party elite. AAN, KC PZPR, mf 2824, Protokół posiedzenia Sekretariatu BO w dniu 26 I 1953 r.

${ }^{29}$ AAN, KC PZPR, 237/VII-151, W sprawie wzmocnienia pracy organizacyjnej wśród kobiet, fol. 7.

${ }^{30}$ Funk, 'A Very Tangled Knot', p. 350.

${ }^{31}$ Nowak, 'Serving Women', pp. 203-07.

${ }^{32}$ Ibid., p. 244. 
areas, governed by separate district, provincial and central management boards and linked to the League only through collective membership. As an autonomous part of the agricultural rings, the Circles of Rural Housewives should also be part of the League of Women and its members should discharge all the obligations arising from the League's statute. Secretariat has also found it advisable to create the League's workplace units'. ${ }^{33}$ 'A new opening' proposed by the League was accepted..$^{34}$ In the period marked by the criticism of the Stalinist era, it was declared necessary for the League to focus more on women's needs (the phrase used was that it should be "closer to women') and less on the transmission of party policy (the view of these tasks as contradictory is quite symptomatic of the time).$^{35}$ The League's focus on the pursuit of propaganda goals, coupled with its disregard for the problems encountered by women following professional careers, running households and raising children, received a lot of criticism. ${ }^{36}$

1966 marked another important halt in the history of the women's movement. In 1965 the League's Board had approached the Central Committee of the PZPR about the organization of the League's convention and the establishment of a special commission to evaluate the state of the women's movement and to 'present the party's leadership with specific conclusions regarding this issue'. Tadeusz Rudolf, deputy head of the party's organizational section, was appointed chairman of the commission. Its members included Stanisława Zawadecka, head of the League of Women, Irena Janiszewska of the CRZZ, a representative of the agricultural rings, three secretaries to the party's provincial committees, and a number of women representing the Trade Unions. ${ }^{37}$ The commission issued a note (January 1966) proposing organizational changes: the National Council of Polish Women (KRKP) to be affiliated to the Polish Committee of the National Unity Front, the strict separation of various organizations' activities and the abolition of the overarching status of the League of Women. In its justification for the proposed changes, the

33 'Sekretariat uznał za niesłuszne tworzenie odrębnej organizacji kobiecej na wsi, posiadającej własne zarządy na szczeblu powiatowym, wojewódzkim i centralnym i związanej z LK tylko poprzez zbiorowe członkostwo. Koło Gospodyń Wiejskich będąc autonomiczną częścią koła rolniczego winno być jednocześnie kołem LK, a jego członkowie winni wykonywać wszystkie obowiązki jakie wynikają ze statutu LK. Sekretariat uznał także za celowe utworzenie kół LK przy zakładach pracy.' AAN, KC PZPR, 237/V/50, Protokół posiedzenia Biura Politycznego, 29 VI 1957, fol. 164.

${ }^{34}$ AAN, KC PZPR, 237/V/52, Notatka w sprawie Zjazdu LK, 1957, fol. 97.

${ }^{35}$ AAN, KC PZPR, 237/V/52, Notatka Wydziału Organizacyjnego w sprawie zjazdu LK, fol. 103-05.

${ }^{36}$ Ibid., Notatka w sprawie zjazdu LK, fol. 106-14.

${ }^{37}$ AAN, KC PZPR, 237/VII/22 (mf 3382). 
commission stated that every section should carry out tasks assigned by the organization of which it was a part, and that the League should focus its' activities in the cities. 'Given that most women are not in employment, remaining beyond the reach of social organizations, and those who are employed can be given an opportunity to participate in some social activities at home - our work in this field is socially very significant' - this argument seems to have been crucial. The party must have been troubled by the fact that urban women who were not professionally active (housewives) were beyond the reach of the women's movement. ${ }^{38}$ In February 1966, the Central Committee of the PZPR's Secretariat issued an instruction 'on the party's work among women' which confirmed the proposed changes.

The instruction included a clear description of the mechanism whereby the women's movement was controlled: the party should supervise 'work among women' by carrying out regular appraisals of women's organizations during party meetings, and by holding separate meetings with female activists representing different women's groups. The supervision was to be exercised through the party's regional committees working systematically with the party members within the Women's Council and within the trade unions' regional managements, the cooperative organizations, the agricultural rings and the League of Women. ${ }^{39}$

A significant change was the re-dissolution of the League's workplace units. As Barbara Nowak has noted, this decision was to the League's detriment, significantly restricting its activity. The network of local League units developed slowly. ${ }^{40}$ Nowak claims that the party took this decision in retaliation for the position adopted by the League. She believes that the organization's workplace units were considered 'inconvenient' by

38 'Biorąc pod uwagę fakt, że większość kobiet nie pracuje zawodowo i znajduje się poza zasięgiem wychowawczego oddziaływania organizacji społecznych oraz fakt, że kobiety pracujące zawodowo mogą być również objęte pracą społeczną w miejscu zamieszkania - praca na tym terenie posiada wielkie znaczenie społeczne', AAN, KC PZPR, mf 3383, Notatka w sprawie zmian w zasadach organizacyjnych ruchu kobiecego, January 1966.

39 'Polityczne kierownictwo ze strony partii pracą wśród kobiet powinno być realizowane przez: okresowe dokonywanie ocen działalności organizacji na posiedzeniach instancji partyjnych, narady i spotkania z aktywem kobiecym poszczególnych środowisk [...]. Partyjne kierownictwo powinny sprawować komitety wojewódzkie przez systematyczną pracę z zespołem partyjnym w Radzie Kobiet oraz przez pracę z członkami partii w wojewódzkich kierownictwach związków zawodowych, organizacji spółdzielczych, kółek rolniczych i LK’, AAN, KC PZPR, mf 3383, Instrukcja Sekretariatu KC 'O pracy partyjnej wśród kobiet', fol. 385-86.

${ }^{40}$ AAN, KC PZPR, XII/2899, Analiza realizacji instrukcji Sekretariatu KC o pracy partyjnej wśród kobiet, October 1970. 
the authorities ${ }^{41}$ However, analysis of surviving documents shows that this interpretation is only partly justified. In 1966 female activists were involved in the decision-making process and were not forced to passively accept the new measures.

The reason for the establishment of the KRKP was to define the direction of work among women, to characterize its main tasks, to coordinate efforts undertaken by different female groups, to represent women's interests before the state authorities and to ensure women's representation within international organizations'. ${ }^{42}$ The Council came to represent the whole women's movement. Consequently, the League lost control of the Circles of Rural Housewives and became equal in status to all the other female groups. The institution of 'collective membership' was liquidated. A model in which the trade unions were women's sole workplace organization was reinstated. The KRKP was expected to cooperate with the CRZZ, the Main Cooperative Council, the Central Board of Agricultural Rings, the League of Women and the Military Families Association. The Council continued in this form until 1983. The principle of subordination to the party was included in its statute in $1980 .{ }^{43}$

The existence of the Solidarity trade union had substantial impact on the League of Women. In the autumn of 1981, the Eighth General Convention passed a resolution establishing the Government Office for Women and restoring the League of Women as a member of the Women's World Democratic Federation. One of the more important demands concerned restoration of the League's workplace units. The establishment of the Polish Women's Association was discussed again, although this time less forcefully (I discuss it below). In November 1981 the PZPR's Politburo discussed a report on the situation of women. The division into 'environmental organizations' was preserved, but the Politburo gave assent to restore the League's workplace units. ${ }^{44}$ It was decided to create the Women's Commission within the Central Committee and its counterparts within the party's provincial committees. Headed by Politburo member Zofia Grzyb, the Commission began its work directly after the introduction of martial law in the Spring of 1982. It is quite typical that the Commission's Presidi-

${ }^{41}$ Nowak, 'Serving Women', pp. 219-20.

${ }^{42}$ 'Dla określenia podstawowych kierunków i najważniejszych aktualnych zadań pracy wśród kobiet, dla koordynacji pracy poszczególnych środowisk, dla reprezentacji interesów i potrzeb kobiet wobec władz państwowych i reprezentacji kobiet polskich w organizacjach międzynarodowych', AAN, KC PZPR, mf 3383, Instrukcja Sekretariatu KC 'O pracy partyjnej wśród kobiet'.

43 AAN, OK FJN, 983, Nowy regulamin KRKP, 1980.

${ }^{44}$ AAN, KC PZPR, XLII/18, Notatka o sytuacji w ruchu kobiecym, 1982. 
um contained no activists of the women's movement, although the issues it dealt with differed little from those addressed by various women's organizations. ${ }^{45}$

The history of the structural changes in the women's movement reveals the mechanism whereby it was dealt with. The most important debates and decisions were elaborated within the Central Committee of the PZPR, either by the Secretariat or the Politburo. High ranking activists were, at least formally, involved in the process. Changes in the organization of the women's movement were consulted with its members. Under the adopted model particular organizations proposed implementation of specific reforms. It is hard to say to what extent the authorities inspired specific proposals and to what extent the content of formal documents was agreed on during unofficial meetings. However, even if it is assumed that various organizations had a say in matters and were allowed to put forward specific proposals, their implementation clearly indicates with whom the 'final decisions' rested. In 1953, when the Women's Section was dissolved, its dissolution was proposed by the authorities. Why would the section want to dissolve itself and its members lose much of their power? A similar scenario unfolded in Yugoslavia where in 1953 the Women's Anti-Fascist Front was dissolved. Chiara Bonfiglioli claims that female activists were involved in this decision. This view is not shared by Funk who adds that female activists tended to favour the party's interests. ${ }^{46}$ In 1966 the changes were brought about in a similar way. Female activists made up the majority of the Central Committee of the PZPR's special commission and must have had a hand in determining their direction. However, the decisions subsequently taken had a harmful effect on the foremost women's organization, that is, the League of Women (through the abolition of its workplace units). The party's interests took precedence. The weakening of the League of Women - most evident in 1966 following the dissolution of its workplace units and the KRKP's establishment - shows that the party dictated the League's position in the structure of power and did not want to let it become too influential. The remaining branches of the women's movement were part of other structures such as trade unions or agricultural rings.

${ }^{45}$ AAN, KC PZPR, XLII/18, Ustalenia Komisji Kobiecej KC PZPR z pierwszego posiedzenia w dniu 15 marca $1982 \mathrm{r}$.

${ }^{46}$ Funk, 'A Very Tangled Knot', p. 347. 


\section{Organizations - supplicants}

In the section above I have summarized the most important changes the women's movement underwent in the years 1945-89. I have also described the way in which decisions regarding it were taken. My analysis shows that at least twice, in 1957 and 1981, the party took grass-roots proposals into consideration. In the following paragraphs I present the women's organizations as playing a somewhat different role, that of supplicants whose proposals either were not implemented or were entirely ignored.

The League of Women was treated as a supplicant and often dismissed empty-handed by the communist party. This was exemplified through the successive conventions to be held every four years under the League's Statute. In March 1949 the Women's Section presented the Politburo with proposals regarding the women's movement, including organization of a first League convention in October $1949 .{ }^{47}$ The Politburo consented for this to be held in March 1950, but it was subsequently rescheduled. In January 1951 Edwarda Orłowska, then head of the Women's Section, wrote to the Central Committee of the PZPR's Secretariat about the matter (thus acting as an intermediary between the League's leadership and the party). ${ }^{48}$ The National Congress of Women was ultimately held as late as March $1951 .^{49}$

The Second Convention was scheduled to take place in the autumn of 1956, but it was postponed until July 1957. The next, having been put off several times, was held two years later than was originally planned. First scheduled for the summer of 1960 , then for $1961,{ }^{50}$ it was finally organized in 1962 and its duration reduced from five to three days. ${ }^{51}$ The Fourth Convention was held according to plan, in May 1966, a few months after the Central Committee of the issued the instruction on the 'party's work among women', in other words when the most important decisions had already been taken. Over the next two decades the League's conventions were held on schedule, but the organization's relations with the party did not change.

${ }^{47}$ AAN, KC PZPR, mf B 49071, Zadania i podstawy organizacyjne masowej pracy wśród kobiet (opracowane przez Wydział Kobiecy). Tezy dla biura Politycznego KC, March 1949.

${ }^{48}$ AAN, KC PZPR, mf B 49938, Pismo Edwardy Orłowskiej do Sekretariatu KC PZPR, fol. 6.

${ }^{49}$ AAN, KC PZPR, 237/V/97, Skład delegatek na Ogólnopolski Kongres Kobiet, March 1951.

${ }^{50}$ AAN, KC PZPR, 237/V/447, Notatka w sprawie przygotowań do III Krajowego Zjazdu LK, January 1961, fol. 11.

${ }^{51}$ AAN, KC PZPR, 237/VII/19 (mf 3379), Notatka w sprawie III Zjazdu Ligi Kobiet. 
In applying for permission to organize the League's convention, its leaders submitted their organization's activity report, the papers and resolutions to be delivered during the convention and proposals on the League's board composition. In a way typical of PRL reality, the Central Committee of the PZPR, assisted by the League's leaders, staged the League's conventions which, after all, had a crucial impact on the way it functioned. The organizational section recommended a candidate for the position of League chairman while candidates for the League's management board were nominated in consultation with the party's provincial committees. ${ }^{52}$

The 1974 attempt to restructure the women's movement provides an interesting example of a failed bottom-up initiative. At the time most of its provincial branches advocated reform and wanted to establish a single women's organization, supported by the party's provincial committees. Female activists devised a plan of creating one organization called the Polish Women's Association or, alternately, two organizations, one for the countryside and one for the cities. They also wanted the Central Committee of the PZPR to issue a new instruction on 'work among women'. The new organization would be stronger and have greater impact among women, especially on their political views. Points were raised about the necessity of acting in support of 'all women'. It was argued that many organizations overlapped, especially in the countryside. Complaints were also made that the movement suffered from fragmentation (ideological disintegration, local priorities, personal conflicts) and that women's councils were façade institutions. Of the sixteen voivodeships, thirteen put forward this proposal. Interestingly, there was a divergence of opinion regarding the restoration of the League's workplace units; some activists believed that their organizations should be active in women's homes and not their workplaces. ${ }^{53}$ Since it was not particularly popular in the period under discussion (in Małopolska the League had about twenty thousand members, while the number of women belonging to the Rural Housewives' Associations came to over ninety thousand), the League of Women was not perceived as an organization capable of uniting the entire women's movement.$^{54}$ Reports sent in from the party's provincial committees were, with a few exceptions, extremely critical of the League's activities. There were even suggestions to dissolve it altogether. It was also mentioned that the Working Women's

${ }^{52}$ AAN, KC PZPR, XII/2912, Notatka w sprawie VI Krajowego Zjazdu Ligi Kobiet, February 1975.

${ }^{53}$ AAN, KC PZPR, 237/XII-2909, Materiały nadesłane z KW, 1974.

${ }^{54}$ AAN, KC PZPR, 237/XII-2909, Uwagi dotyczące aktualnych problemów struktury i funkcjonowania ruchu kobiecego w Krakowskiem, 9 II 1974. 
Commissions (affiliated to the CRZZ) were a fiction. Many of them were liquidated. The criticism of arrangements introduced in the party's 1966 instructions was quite explicit.

Analysis of the history of the women's movement in PRL raises doubt as to whether any arrangement at all could have resulted in the improvement of the movement's effectiveness, which, after all, the authorities considered to lie in its ability to implement the party's programme. The Circles of Rural Housewives functioned well, but minimized their 'ideological efforts'. Ensuring the uniformity across the movement, the creation of a single organization would however limit its relative autonomy. The discussion held in 1974 is presented here as an example of disregard for grass-roots initiatives by the authorities, who ignored proposals to unify the women's organizations. The Polish Women's Association was not brought into being, nor were any other changes effected.

The Circles of Rural Housewives long and unsuccessful efforts to break ties first with the League of Women and then the KRKP are another example of ignored proposals by women's organizations. I have already mentioned that in 1957 the communist authorities refused to consent to the creation of a separate rural women's organization. In 1980, the Circles of Rural Housewives, although doing well in comparison with other organizations, wanted to sever all ties with them, but the idea was not approved..$^{55}$ Although in the years 1980-81 both the party and other organizations were in a state of commotion, the Politburo did not take into consideration the idea of liquidating the National Council of Polish Women. It was not until after the introduction of martial law that the discussion was resumed. It was decided to liquidate the KRKP and replace it with a 'new platform for women's cooperation'. Matters were further complicated by the establishment of the Patriotic Movement for National Revival. ${ }^{56}$

It is quite typical that the League's proposals gained acceptance in times of political crises. The weaker the party grew the greater the autonomy enjoyed by the women's movement. The first crisis occurred in 1957, when the League - decimated by political thaw and ideological and organizational disintegration - sought to regain its position by restoring its workplace units. The second crisis came in the autumn of 1981.

An idea never implemented concerned the abolition of women's night work. In the first post-war years night-work by women was contrary to existing regulations (it was subject to special authorization), but given the state of the country's economy women's organizations hesitated on the

\footnotetext{
${ }^{55}$ Zob. Jarska, 'Between the Rural Household and Political Mobilization'.

${ }^{56}$ AAN, KC PZPR, XLII/18, Notatka o sytuacji w ruchu kobiecym, 1982.
} 
advisability of calling for an implementation of the rules in force ${ }^{57}$ Night-work was legalized in 1951. In the late 1950s female activists began to call for a change to the 1951 legislation. The demand resurfaced in a resolution adopted during the League's Special Convention held in 1981. In passing it, the League called for the ratification of the International Labour Organization's Convention. This act also included a demand to equate women's domestic work with paid employment (by grant of equal social benefits).

\section{Programmes and proposals}

The women's movement in PRL was complex, widespread and evolved over time. It is impossible to discuss here all the important strands of its history. Various aspects of League's of Women activity have already been covered by other scholars. In this section I would like to provide a few examples illustrating how female activists' agenda fitted into the wider framework of the communist system. This does not mean that women's organizations did not act in favour of women. It only shows how the women's movement was instrumentalized by the communist authorities. This instrumentalization is clear and has been analysed many times for the Stalinist period. For this reason my focus here is on the period after 1956.

The main goal of the party was to shape women's political outlook. The only change in this pursuit was its means. During the first post-war years, the PPR strove to mobilize women to join the party. However, as early as 1949 it was found more desirable to rely on the League of Women as a means of influencing women's attitudes. ${ }^{58}$ 'The party treats social organizations as a platform on which to build a wide support for its policy', as was remarked by the Central Committee of the PZPR regarding the address to be delivered during the League's Sixth Convention held in $1975 .^{59}$ From the early post-war years the party was convinced of the need to send women a specific ideological message. ${ }^{60}$ The organization was tasked with building support for party policy. In March 1968, the question of whether to issue a statement on recent events at universities was debated during the session of the League's Council. Ultimately, an appeal was drafted containing the following sentence: 'the KRKP's Presidium condemns subversive actions undertaken by Zionist forces

${ }^{57}$ Natalia Jarska, Kobiety z marmuru. Robotnice $w$ Polsce $w$ latach 1945-1960, Warsaw, 2015, pp. 63-65.

${ }^{58}$ Eadem, 'Kobiety w PZPR 1948-1956. Paradoksy mobilizacji politycznej kobiet w stalinizmie', in Kobiety 'na zakręcie' 1933-1989, pp. 36-38.

${ }^{59}$ AAN, KC PZPR, XII/2912, Tezy do przemówienia na Zjeździe LK, 1975.

${ }^{60}$ Jarska, Frauen. 
and political bankrupts'. The Council appealed to teachers and parents to ensure that young people were given 'proper education' ${ }^{61}$ Following this the women's movement became increasingly active in the field of education ('the March events have showed how important it is that the whole society, all its organizations, and especially all women, show concern for the socialist education of youth' ${ }^{\prime 62}$ ). This is one of many examples for the effect of current events on the women's movement and its agenda.

Concern for current party objectives played a part even in the movement's structural changes. That this was the case was explicitly expressed by President of the Council of the State Edward Ochab during the KRKP's first meeting: 'the Council should give much thought to how best to use the talent and abilities of hundreds of thousands of professionally inactive women. Almost all social and political goals, including the consolidation of progressive forces and the reinforcement of national unity, can be achieved with women's active participation. These tasks are of great importance, especially now when the Church's reactionary part can be seen stepping up its efforts to mobilize women against the policy of our state'. ${ }^{63}$ Perhaps the existence of the League's workplace units was to women's advantage, but they could have no impact on those who were not in paid employment and whom the authorities considered to be susceptible to Church influence. In its first years of existence the KRKP became engaged in promoting 'secular rituals', evidence that it was given a role in secularization efforts. It is not without significance that the establishment of the KRKP coincided with celebrations of the thousandth anniversary of the adoption of Christianity in Poland, and with an intense ideological struggle between the PZPR and the Church. In the 1970s, the League received this praise in the course of its Convention: 'you teach women new patterns of family life, you change their habits and contribute to family life's secularization' ${ }^{64}$

${ }^{61}$ AAN, OK FJN, 954, Protokół z posiedzenia prezydium 18 III 1968.

${ }^{62}$ AAN, OK FJN, 954, Notatka z prezydium KRKP, 22 X 1968.

63 'Rada w swej działalności winna poświęcić dużo miejsca jak najszerszemu wykorzystaniu talentów, sił i zdolności, jakie reprezentują setki tysięcy kobiet niepracujących zawodowo. Wszystkie niemal bowiem problemy ekonomiczne kraju, społeczne, zwłaszcza konsolidacja postępowych sił społecznych i umacnianie jedności narodu, mogą być rozwiązane do końca przy zaangażowanym udziale kobiet polskich. Ma to szczególne znaczenie zwłaszcza obecnie, w okresie antyludowej i antypaństwowej aktywizacji reakcyjnej części episkopatu i kleru, który liczy w prowadzonej obecnie przez siebie mobilizacji przeciwko polityce naszego państwa na zaangażowanie w niej kobiet polskich.' AAN, OK FJN, 952, Protokół z pierwszego posiedzenia KRKP w dniu 16 IV 1966.

64 'Uczycie kobiety nowych wzorców życia rodzinnego, zmieniacie zwyczaje 
Political goals, whether immediate or general, were not the only objectives set for women's organizations. The PPR/PZPR's political programme included advocacy for gender equality and the women's movement naturally expected to contribute to its realization. In a 1966 speech inaugurating the KRKP's activity. Stanisława Zawadecka (president of the ZGLK and the KRKP) stated: 'old-fashioned habits and traditionally-sanctioned views of women's social, professional and family roles still make themselves felt. There are men of good will, including progressive male and female activists, who still cling to the traditional ways of defining the family life, women's role in it, the range of women's professional responsibilities and the extent of their rights and abilities. It is sometimes falsely argued that women are not fit to serve in leadership positions and that they can be paid less than men, since their work is only a supplement to the family budget while men as heads of their families are responsible for families' financial security. This line of argument is often used to justify underpayment of women who are equal to men in terms of skills, experience and position' ${ }^{65}$ Zawadecka's statement expressed female organizations' commitment to work towards the goal of gender equality.

In practice, after 1956, the foremost means of pursuing this goal was by enabling women to combine their professional and household roles and by attempting to raise their status in the field of paid labour. The League of Women provided women with career guidance and women's organizations called for extending labouring women's rights. Activists usually relied on statistics for measuring gender equality. They counted how many women held leading positions, how many had vocational education, how many held university degrees, etc. Worth noting are also

i obyczaje, wpływacie na laicyzację życia rodzinnego', AAN, KC PZPR, XII/2912, Tezy do przemówienia.

${ }^{6}$ 'Przeżytki w obyczajowości, obwarowane tradycją poglądy na rolę i pozycję kobiety w pracy zawodowej, w społeczeństwie i rodzinie - jeszcze często dają znać o sobie. Nierzadko jeszcze ludzie najlepszej woli, a nawet postępowi skądinąd działacze i działaczki nie wyzwolili się całkowicie z tradycyjnego widzenia modelu rodziny, roli w niej kobiety, jak również zakresu i zasięgu czynności i odpowiedzialności zawodowej kobiety, skali jej możliwości i uprawnień. Zdarza się, że tu i ówdzie używa się pseudoargumentów, że kobieta nie nadaje się do pełnienia odpowiedzialnych funkcji, że jej zarobek może być niższy od mężczyzny, bo przecież jej praca to tylko uzupełnienie budżetu rodzinnego, a mężczyzna jako głowa rodziny ponosi wszelką finansową odpowiedzialność. Ta [...] argumentacja towarzyszy zdarzającym się niestety faktom zaniżonych płac kobiet o równym z mężczyznami poziomie przygotowania, stażu pracy i stanowisku.' AAN, OK FJN, 954, Stenogram z obrad KRKP, 27 VI 1968. Zawadecka was in charge of both structures until mid-1968, when she resigned to emigrate with her husband to Israel. She was replaced in both positions by Maria Milczarek, a party activist who had not before been connected with the women's movement. 
initiatives such as the press award for texts commenting on women's problems (first granted by the KRKP in 1970). ${ }^{66}$ Affiliated to the League of Women was the Section of Women Lawyers whose task was to organize legal aid and popularize the knowledge of family and guardianship law. ${ }^{67}$

The women's movement was preoccupied with a perceived subsidence to within the range of 'women's issues', which, in turn, were considered to include not only career advancement, but also household activities and the raising of children and youth. After 1956 women's unemployment became a significant problem. Efforts to bring it down consisted mainly of propagating vocational education. The League of Women, for example, organized career guidance for girls whilst the Women's Council requested that women have access to part-time and evening secondary schools ${ }^{68}$ In the 1970s the CRZZ Women's Commission organized the contest 'we facilitate the life of a labouring woman'. It also did research (in the 1960s and 1970s) into women's professional activity and their working conditions. ${ }^{69}$ In the 1960s the women's movement began to contribute to the knowledge production on women's situation. The research it carried out remains a significant source of information for present-day scholars.

From the end of the 1950s various household issues attracted the attention of not only the League of Women, to which the Household Committee was affiliated, but also other women's organizations. There were over 1,000 'Modern Housewife' and 'Practical Lady' centres and over 3,000 domestic appliances rental centres within the cooperative movement. In 1966 the Circles of Rural Housewives organized dietary and sewing courses attended by more than 200,000 women. ${ }^{70}$ The Women's Council approached the government about great numbers of minor issues regarding the supply and production of household items, as well as the development of services. During meetings with trade and industry representatives, female activists critiqued items available on the market: 'shoes can be bought, but they pinch and are always stiff, and there is a shortage of those size 7 and 8' or 'tights from Zduńska Wola at 130 zlotys per pair are of the same width at the ankle and the thigh', 'brooms -

${ }^{66}$ AAN, OK FJN, 985, Działalność KRKP w latach 1966-1981.

${ }^{67}$ AAN, KC PZPR, XII/2921, Wstępna informacja na temat kierunków działalności Sekcji Kobiet Prawników w latach 1974-1978.

${ }^{68}$ AAN, OK FJN, 971, Pismo od Ministerstwa Oświaty i Szkolnictwa Wyższego, opracowanie pt. 'Zagadnienie kształcenia dziewcząt i kobiet'.

${ }^{69}$ AAN, KC PZPR, XII/2804, Różne materiały z badań.

${ }^{70}$ AAN, OK FJN, 953, Problemy dotyczące gospodarstwa domowego rodziny w Polsce i wynikające stąd wnioski (materiał na posiedzenia KRKP). 
it is shameful that it is impossible to purchase a complete broom, one mounted on a stick. Screw caps and brushes are available but there are no sticks on the market'. ${ }^{71}$

In the 1970s the women's movement was affected by rhetoric the authorities used regarding the family. Various organizations concerned themselves with 'women's issues', but these were defined specifically as 'family' ones. The Łódź branch of the League of Women saw its main task as strengthening the 'unity of the family' by offering a variety of household training and guidance. The 'women's issues' always included 'childcare'.

Women's organizations were also involved with various social problems for which it is difficult to draw a direct link to women. In the 1970s they were expected to organize care for the elderly. The League of Women was involved in running elections to the housing estate councils. ${ }^{72} \mathrm{Va}-$ rious women's organizations also engaged in combating alcoholism. The long list of issues female activists were expected to deal with involved everything which fell under the remit of women according to the authorities. In truth, the women's movement was expected to contribute to solving all sorts of social and everyday life problems.

The above analysis shows that women's organizations in communist Poland after 1956 dealt with a great variety of social issues including those not directly related to women, although of course the spheres of activity in which the women's movement was involved were considered to reflect the spheres of activities of women themselves, and after 1956 the view of these spheres was, setting aside some insignificant changes, rather constant. All the goals pursued by women's organizations were strictly bound up with the policy carried out by the PZPR or by other organizations of which women's various bodies were part. It can hardly be argued that all the tasks were imposed; female activists, most of whom were PZPR members, knew what was expected of their organizations at a given moment. There was a clearly defined range of social issues in which the women's movement, constituting part of the communist system, was to be active.

${ }^{71}$ AAN, OK FJN, 791, Protokół ze spotkania zorganizowanego przez komisję ds. ekonomiki gosp. domowego KRKP z przedstawicielami przemysłu i handlu na Targach Krajowych ‘Jesień 1968’ w Poznaniu w dniu 7 września 1968.

72 AAN, KC PZPR, XII/2918, Informacje o działalności LK, 1973. 


\section{Conclusions}

Analysis of the relations between the women's movement and the communist party shows their coalescence. The former was integrated into the system, and it is often difficult to distinguish between the latter's independent decisions and its assent to female activists' proposals. Not only did the PZPR control, for example, the League of Women, but it also penetrated its structures (this situation was to some extent reciprocal). Female activists did not necessarily hold a negative view of this control. Sometimes they even called for the party to pay their activity more attention. The PZPR was considered to increase these activists' chances of achieving particular objectives. It was also expected to reinforce the message of gender equality and to add cachet to 'work among women' ${ }^{73}$ Moreover, most high-ranking activists were at the same time party members (or belonged to other political organizations), so they had a double identity. In 1975 the party members made up 68 per cent of the League's regional management boards. ${ }^{74}$ At least twice, in 1953 and in 1966, women's movement activists acted to the detriment of their respective organizations, pursuing the party's policy.

The coalescence mentioned above was reflected in the way in which decisions regarding the women's movement were taken and in which women's organizations were assigned their tasks. Relation between the party and the women's movement can be described using the metaphor of marriage in a patriarchal society. Both formed a unit working towards a single goal. However, their marriage was not one of equal partners but a patriarchal one, and their relationship was unequal, with the movement mirroring the traditional role of a woman subordinate to her husband. The final say rested with the Politburo or the Secretariat of the Central Committee of the PZPR, two bodies dominated entirely by men (for most of the period discussed here all their members were male). The League of Women and the National Council of Polish Women remained supplicants whose voices were heard but not always taken into consideration. The party's control of the women's movement was not very strict. Particular organizations knew what was expected of them, although in moments of crises they were able to exert some pressure on the authorities. Being familiar with the role it was given, the women's movement engaged in fields regarded as for the reserve of women. The party's female hand was part of the relatively stable system of roles.

\footnotetext{
${ }^{73}$ AAN, KC PZPR, XII/2910, Notatka z rozmów z działaczkami ruchu kobiecego, 1972.
}

${ }^{74}$ AAN, KC PZPR, XII/2912, Notatka na temat VI Zjazdu LK, March 1975. 
The conclusions to be drawn from the analysis presented above, along with the metaphor of marriage, make it possible to resolve the continuing dispute regarding the issue. As I have mentioned in the preface, both parties to the dispute are partially correct. 'Feminist revisionists', as Nanette Funk has called them, stress the fact that women's organizations actually acted in support of women and of gender equality. A brief review of the actions taken by female activists provides sufficient grounds to advance that thesis. On the other hand, the women's movement was deeply dependent on the communist authorities. For this reason women's organizations in communist states should be perceived as forming part of the system which, one might add, involved itself in some advocacy for gender equality. However, the pursuit of gender equality had to give way to other priorities. Consequently, some of its goals couldn't be achieved and some were never even formulated. In this sense it is impossible to separate the efforts in support of women from those in support of the state. Whether or not they can be referred to as feminist depends on how we define feminism.

In conclusion one must add that the account of relations between the communist party and women's organizations presented here does not provide answers to all the questions that can be asked with regard to the women's movement in Poland in the years 1945-89 (and in the other communist countries). This article presents the movement from the perspective of its centre. Organizations of this magnitude operated in a variety of ways in various places and with differing efficacy. It is important that further research into the topic be properly conceptualized and approached from a perspective that will help (and not hinder) us understand the specific roles the women's movement played. 


\section{Annex}

\begin{tabular}{|c|c|}
\hline Superior (controlling) structure & Subordinate structures \\
\hline $\begin{array}{l}\text { THE WOMEN'S SECTION OF THE } \\
\text { CENTRAL COMMITTEE OF THE PPR } \\
\text { 1946-48 }\end{array}$ & $\begin{array}{l}\text { THE SOCIO-CIVIC LEAGUE OF WOMEN: workplace } \\
\text { units, rural units, the Circles of Rural } \\
\text { Housewives (the KGW) 1945-48 } \\
\text { THE CENTRAL COUNCIL OF TRADE UNIONS - } \\
\text { WOMEN'S SECTION: Women's Offices and } \\
\text { Women's Councils from } 1946 \\
\text { THE FARMER'S SELF-HELP ASSOCIATIONS - } \\
\text { Women's Councils, the KGW }\end{array}$ \\
\hline \multicolumn{2}{|r|}{1948} \\
\hline $\begin{array}{l}\text { THE WOMEN'S SECTION OF THE } \\
\text { CENTRAL COMMITTEE OF THE PZPR } \\
\text { 1948-53 }\end{array}$ & $\begin{array}{l}\text { THE LEAGUE OF WOMEN: workplace units, in } \\
\text { State Agricultural Farms, the Military Families' } \\
\text { Associations } \\
\text { THE FARMERS' SELF-HELP ASSOCIATION: } \\
\text { Women's Communal Councils, the KGW } \\
\text { 1949-66 (collective membership in the League } \\
\text { of Women) } \\
\text { The CRZZ - Women's Councils (1950-53) }\end{array}$ \\
\hline \multicolumn{2}{|r|}{1953} \\
\hline $\begin{array}{l}\text { THE ORGANIZATIONAL SECTION OF } \\
\text { THE CENTRAL COMMITTEE OF THE } \\
\text { PZPR }\end{array}$ & $\begin{array}{l}\text { THE LEAGUE OF WOMEN 1953-57: units in place } \\
\text { of residence } \\
\text { THE FARMERS' SELF-HELP ASSOCIATION: } \\
\text { Women's Councils, Women's Communal } \\
\text { Councils, the KGW 1949-66 (collective } \\
\text { membership in the League of Women) }\end{array}$ \\
\hline \multicolumn{2}{|r|}{1957} \\
\hline $\begin{array}{l}\text { THE ORGANIZATIONAL SECTION OF } \\
\text { THE CENTRAL COMMITTEE OF THE } \\
\text { PZPR }\end{array}$ & $\begin{array}{l}\text { THE LEAGUE OF WOMEN 1957-66: workplace } \\
\text { units, the Communal Boards of the League of } \\
\text { Women, housing estate units, local units } \\
\text { THE CRZZ - WOMEN'S COMMISSION - Women's } \\
\text { Commissions and Labouring Women's } \\
\text { Commissions }\end{array}$ \\
\hline \multicolumn{2}{|r|}{1966} \\
\hline $\begin{array}{l}\text { THE NATIONAL COUNCIL OF POLISH } \\
\text { WOMEN attached to the Bureau of } \\
\text { the National Unity Front 1966-83 } \\
\text { THE SECTION OF SOCIAL } \\
\text { ORGANIZATIONS, SPORT AND } \\
\text { TOURISM OF THE CENTRAL } \\
\text { COMMITTEE OF THE PZPR 1977-81 }\end{array}$ & $\begin{array}{l}\text { THE LEAGUE OF WOMEN (without its workplace } \\
\text { units), from } 1967 \text { Militia Families Groups } \\
\text { THE CRZZ - WOMEN'S COMMISSION (until 1980) } \\
\text { THE CENTRAL BOARD OF THE AGRICULTURAL } \\
\text { RINGS - the Main Council of the Circles of } \\
\text { Rural Housewives } \\
\text { THE NATIONAL SECTION OF COOPERATIVE } \\
\text { WOMEN }\end{array}$ \\
\hline \multicolumn{2}{|r|}{1981} \\
\hline $\begin{array}{l}\text { THE WOMEN'S COMMISSION } \\
\text { WITHIN THE CENTRAL COMMITTEE } \\
\text { OF THE PZPR (the Socio-Labour } \\
\text { Section) 1982-89 }\end{array}$ & $\begin{array}{l}\text { THE LEAGUE OF POLISH WOMEN: the restoration } \\
\text { of workplace units (1981) } \\
\text { THE CIRCLES OF RURAL HOUSEWIVES AND THE } \\
\text { NATIONAL SECTION OF COOPERATIVE WOMEN }\end{array}$ \\
\hline
\end{tabular}




\section{Summary}

Over the past few years feminist historiography has been engaged in a debate on the role and character of women's organizations in the state-socialist countries after 1945 . This article is a contribution to that debate. By analysing some aspects of the women's movement in Poland, especially its relation to the communist party and program, I seek to highlight issues that have so far been omitted from researchers' attempts to grasp the nature of these kinds of organizations. Debate on their relation to the party, especially after 1956, has been absent from Polish historiography. Analysis, based mainly on the party files, shows that women's organizations should be treated as part of the communist system and the roles they played should be understood in the context of the system's policies. The relation between the party and the women's movement can be represented by the metaphor of a patriarchal, unbreakable marriage, one based on strict hierarchy and clearly defined roles for both spouses.

(Translated by Artur Mękarski) (Proofreading by Yelizaveta Crofts)

\section{Bibliography}

Bonfiglioli, Chiara, 'Women's Political and Social Activism in the Early Cold War Era: The Case of Yugoslavia', Aspasia, 8, 2014, pp. 1-25.

Daskalova, Kassimira, 'How Should We Name the "Women-Friendly" Actions of State Socialism?', Aspasia, 1, 2007, pp. 214-19.

Donert, Celia, ‘Women's Rights in Cold War Europe: Disentangling Feminist Histories', Past \& Present, 218, 2013, suppl. 8, pp. 180-202.

Fidelis, Malgorzata, 'Equality through Protection: The Politics of Women's Employment in Postwar Poland, 1945-1956', Slavic Review, 63, 2004, 2, pp. 301-24.

Fidelis, Malgorzata, Women, Communism, and Industrialization in Postwar Poland, Cambridge: Cambridge University Press, 2010.

Funk, Nanette, 'A Very Tangled Knot: Official State Socialist Women's Organizations, Women's Agency and Feminism in Eastern European State Socialism', European Journal of Women's Studies, 21, 2014, 4, pp. 344-60.

Ghodsee, Kristen, 'Pressuring the Politburo: The Committee of the Bulgarian Women's Movement and State Socialist Feminism', Slavic Review, 73, 2014, 3, pp. 538-62.

Ghodsee, Kristen, 'Untangling the Knot: A Response to Nanette Funk', European Journal of Women's Studies, 22, 2015, 2, pp. 248-52.

Grabowska, Magdalena, 'Bits of Freedom: Demystifying Women's Activism under State Socialism in Poland and Georgia', Feminist Studies, 43, 2017, 1, pp. 141-68. Grabowska, Magdalena, 'Bringing the Second World In: Conservative Revolution(s), Socialist Legacies, and Transnational Silences in the Trajectories of Polish Feminism', Signs, 37, 2012, 2, pp. 385-411. 
Haan, Francisca de, 'Continuing Cold War Paradigms in Western Historiography of Transnational Women's Organisations: The Case of the Women's International Democratic Federation (WIDF)', Women's History Review, 19, 2010, 4: International Feminisms, pp. 547-73.

Jarosz, Dariusz, 'Idee, programy i realia. Funkcje Ligi Kobiet w porządku instytucjonalnym Polski Ludowej (1945-1957)', in Działaczki społeczne, feministki, obywatelki... Samoorganizowanie się kobiet na ziemiach polskich po 1918 roku (na tle porównawczym), 2 vols, ed. Agnieszka Janiak-Jasińska, Katarzyna Sierakowska and Andrzej Szwarc, Warsaw, 2008-09.

Jarska, Natalia, 'Between the Rural Household and Political Mobilization - The Circles of Rural Housewives in Poland 1946-1989', in Countryside and Communism in Eastern Europe: Perceptions, Attitudes, Propaganda, ed. Sorin Radu and Cosmin Budeanca, Zürich: LIT, 2016.

Jarska, Natalia, 'Frauen in den polnischen kommunistischen Parteien PPR/ PZPR - die Paradoxe der Frauenpolitik', Jahrbuch für Historische Kommunismusforschung, 2015, pp. 75-94.

Jarska, Natalia, 'Kobiety w PZPR 1948-1956. Paradoksy mobilizacji politycznej kobiet w stalinizmie', in Kobiety 'na zakreccie’ 1933-1989, ed. Ewa Chabros and Agnieszka Klarman, Wrocław: Instytut Pamięci Narodowej - Komisja Ścigania Zbrodni przeciwko Narodowi Polskiemu, 2014, pp.33-49.

Jarska, Natalia, Kobiety z marmuru. Robotnice w Polsce w latach 1945-1960, Warsaw: Instytut Pamięci Narodowej - Komisja Ścigania Zbrodni przeciwko Narodowi Polskiemu, 2015.

Jarska, Natalia, 'Komisja Kobieca CRZZ wobec problemów kobiet pracujących (1956-1970)', Polska 1944/45-1989. Studia i materiały, 9, 2010, pp. 305-28.

Jarska, Natalia, 'Liga Kobiet w terenie. Działalność Zarządu Dzielnicowego Poznań-Wilda w latach 1956-1966', in Letnia Szkoła Historii Najnowszej 2009. Referaty, ed. Łukasz Kamiński and Tomasz Kozłowski, Warsaw: Instytut Pamięci Narodowej - Komisja Ścigania Zbrodni przeciwko Narodowi Polskiemu, 2010, pp. 149-58.

Marcinkiewicz-Kaczmarczyk, Anna, 'Koła Rodzin Milicyjnych - powstanie, organizacja i praca propagandowa', Czasopismo Naukowe Instytutu Studiów Kobiecych, 2017, 1, pp. 28-47.

Miroiu, Mihaela, 'Communism Was a State Patriarchy, Not State Feminism', Aspasia, 1, 2007, pp. 197-201.

Nowak, Barbara, 'Constant Conversations: Agitators in the League of Women in Poland during the Stalinist Period', Feminist Studies, 31, 2005, 3, pp. 488-518.

Nowak, Barbara, 'Serving Women and the State. The League of Women in Communist Poland', PhD diss., Ohio State University, 2004.

Nowak, Barbara, “"Where Do You Think I Learned How to Style My Own Hair?”: Gender and Everyday Lives of Women Activists in Poland's League of Women', in Gender Politics and Everyday Life in State Socialist Eastern and Central Europe, ed. Shana Penn and Jill Massino, New York: Palgrave Macmillan, 2009, pp. 45-58. 
Nowakowska-Wierzchoś, Anna, 'Społeczno-Obywatelska Liga Kobiet (1945-1949) i Związek Kobiet Polskich im. Marii Konopnickiej we Francji (1944-1950) - dokumenty programowe', Komunizm. System, ludzie, dokumentacja, 2013, pp. 251-79. Popa, Raluca Maria, 'Translating Equality between Women and Men across Cold War Divides: Women Activists from Hungary and Romania and the Creation of International Women's Year', in Gender Politics and Everyday Life in State Socialist Eastern and Central Europe, ed. Shana Penn and Jill Massino, New York: Palgrave Macmillan, 2009, pp. 59-74.

Stańczak-Wiślicz, Katarzyna, 'Household as a Battleground of Modernity. Activities of the Home Economics Commitee Affiliated to the League of Women (1957-80)', Acta Poloniae Historica, 115, 2017, pp. 123-50.

Stasiewicz, Agnieszka, 'Działalność Społeczno-Obywatelskiej Ligi Kobiet w latach 1945-1948 na Białostocczyźnie w świetle dokumentów PPR', in Kobiety 'na zakręcie' 1933-1989, ed. Ewa Chabros and Agnieszka Klarman, Wrocław: Instytut Pamięci Narodowej - Komisja Ścigania Zbrodni przeciwko Narodowi Polskiemu, 2014, pp. 51-78.

Zimmermann, Susan, 'Gender Regime and Gender Struggle in Hungarian State Socialism', Aspasia , 4, 2010, pp. 1-24.

Bi og ra phy: Natalia Jarska - Assistant Professor at the Institute of History of the Polish Academy of Sciences. Her scholarly interests include the history of women and gender in post-war Poland. She has published, among other things, Kobiety z marmuru. Robotnice w Polsce w latach 1945-1960 (Warsaw, 2015). 